\title{
An evaluation of two pastoral dairy production systems using automatic milking technology
}

\author{
J. JAGO and J. BURKE \\ DairyNZ, Private Bag 3221, Hamilton \\ jenny.jago@dairynz.co.nz
}

\begin{abstract}
The objective of this study was to evaluate the performance of two pastoral farming systems using automatic milking systems (AMS). Two farmlets were established at the DairyNZ Greenfield Farm and were evaluated over a single lactation. The GRASS farmlet (92 cows, 3.2 cows/ha) was self-contained except for $2 \%$ of the diet fed as supplement in the AMS. In the GRASS+ farmlet ( 72 cows, 3.6 cows $/$ ha) $18 \%$ of the diet was from feed grown off the milking platform. Modelling the economic performance of the two systems showed a greater operating profit for the GRASS system at milk payouts ranging from $\$ 4.50$ to $\$ 6.50 / \mathrm{kgMS}$. The field study showed that AMS can be successfully integrated into both all-pasture and higher supplementary feed pastoral dairy production systems. The design of profitable farming systems incorporating AMS technology should consider maximising milksolids per AMS through both milking frequency and ratio of cows per AMS.
\end{abstract}

Keywords: grazing, pasture management, economic evaluation

\section{Introduction}

Dairy production in New Zealand is based on lowcost, efficient farming systems that utilise intensive grazing to grow and harvest high quality pasture to produce milk. Automatic milking systems (AMS) are a technology that has the potential to reduce the labour cost associated with milking and improve the lifestyle and work environment for farm staff. The Greenfield Project was established in 2001 to test the viability of automatic milking in New Zealand pastoral farming systems. Following the successful development phase a herd of 180 cows was milked by two AMS on the 54 hectare, all-year grazing (Greenfield Farm) farm (Jago et al. 2004; Davis et al. 2005).

Two farmlets were established on the Greenfield Farm in 2008 to evaluate the performance of production systems typically found in New Zealand. DairyNZ uses a standard classification that categorises farms into one of five production systems based on the timing, purpose and amount of non home-grown feed used (Dairy Economic Survey 2008-2009; Hedley et al. 2006). The systems range from all grass, no supplement imported (10\% of farms) to at least $30 \%$ of total feed imported and fed either in early and late lactation or all year round, and including grazing for dry cows $(<5 \%$ of farms). The latter typically has a higher stocking rate, higher production per cow and per hectare and the herd tends to be larger than in the former system.

The capacity of an AMS is an important consideration in farm systems design. Practical utilisation of fully automated milking systems has been measured at around $80 \%$ (daily range $65-85 \%$ ), allowing for connection failures, technical problems and cleaning down-times (Halachmi 1999). Field experience suggests that in systems where grazed pasture is the predominant diet, about 140 milkings can be carried out per AMS each day. These milkings can be achieved by milking fewer cows more often (more suited to higher input systems with higher yielding cows) or more cows less often (more suited to lower input systems with lower yielding cows) (Jago et al. 2007), with yield and milk harvest rate determining the total output of an AMS.

The objective of the study was to evaluate the performance of an all-grass system with a high number of cows per AMS, and a higher feed input system with a lower ratio of cows to AMS.

\section{Methods}

\section{Animals and design of farmlets}

The existing Greenfield cows were divided into two spring calving herds which were managed on adjacent farmlets from June $1^{\text {st }} 2008$ to $30^{\text {th }}$ April 2009. Herds were balanced for age (mean 5.3 years, range 2-14 years), breed (84\% Friesian, 4\% Jersey, 12\% Crossbred), genetic merit expressed as breeding worth $(\$ B W$, average $=135,2007)$ and expected calving date. After calving, each herd had continuous access to one of the two Fullwood Merlin (Fullwood, UK) AMS throughout the lactation. The 28.8 ha GRASS farmlet ran 92 cows ( 3.2 cows/ha). A small quantity of concentrate (up to $0.5 \mathrm{~kg}$ per cow per day; wheat nuts) was fed in the AMS to assist with cow flow. With the exception of the concentrate ( $2 \%$ of the total diet) the diet was grazed pasture supplemented during periods of pasture deficits (daily offered pasture less than $13.5 \mathrm{~kg}$ / cow/day) with silage made from within the farmlet and fed at pasture. The 20 ha GRASS+ farmlet ran 72 cows 
Figure 1 Farm layout for the GRASS (shaded with dots) and GRASS+ (unshaded) farmlets, the location of the milking parlour, the main grazing areas (A: morning, B: afternoon, and C: evening) in the respective farmlets, milking parlour housing two AMS, dual laneways and selection units ( $\square$ ). The area that was not part of the milking platform and was used to feed cows when not lactating and to grow non home-grown silage is shaded grey on the GRASS+ farmlet.

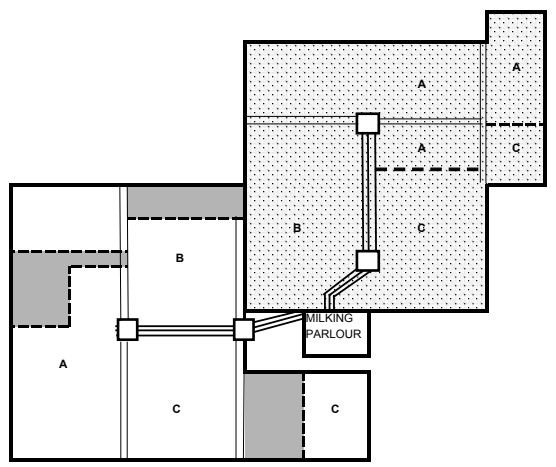

(3.6 cows/ha). Feed grown off the farmlet was $18 \%$ of the diet and consisted of a mixture of grass silage (fed at pasture) and concentrate (48\% each of maize and barley, $4 \%$ molasses, fed in the AMS), ranging from 0.8-3.7 kg DM /cow/day.

\section{Pasture management and farm configuration}

Pasture species on both farmlets was mainly perennial ryegrass (Lolium perenne) and white clover (Trifolium repens). Farmlets were managed independently using standard best practice decision rules (Macdonald \& Penno 1998) for a rotational grazing system, with 3 daily allocations of pasture using temporary fences with back fencing. Access to fresh areas of pasture was at $8 \mathrm{am}, 2 \mathrm{pm}$ and $11 \mathrm{pm}$ daily via remote selection units located on dual raceways (Fig. 1) as detailed in Jago et al. (2004). Milking frequency targets were set within the herd management software, aiming to achieve an average of 1.5 and 2.0 milkings per day across the season for the GRASS and GRASS+ herds, respectively (Crystal 0.44, Fullwood Fusion, Holland). Upon entering a selection unit an electronic identification device was read and the cow drafted accordingly. All cows due for milking went to the milking parlour, while cows not due for milking were either directed back to the grazing area or to new pasture, depending on the time of the visit. Each farmlet received an annual total of $151 \mathrm{~kg} \mathrm{~N} / \mathrm{ha}$. An annual maintenance fertiliser dressing was applied to both farmlets at a rate of 685 $\mathrm{kg} / \mathrm{ha}$ in March 2008 (76\% Super Ten, 4\% Calmag, 5\% Durasul Sulphur, 7\% salt bulk and 7\% potash).

\section{Measurements}

Pasture cover (kg DM/ha) for each farmlet was estimated weekly using an electronic Rising Plate Meter $(360 \mathrm{~mm}$ diameter, 315 g plate weight; Farmworks, Fielding, New Zealand). Total pasture grown and pasture eaten was estimated using the Pasture Eaten Calculator V1.4 July 2007 (http://www.dairynz.co.nz/page/ pageid/2145836732/Production\%20and\%20 Feeding\# PastureEatenCalculator). The energy requirements for grazing dairy cows used in the Pasture Eaten Calculator are based on measurements and assumptions described by Nicol \& Brookes (2007).

Milk yield was recorded automatically by the herd management software (Crystal 0.44, Fullwood Fusion, Holland). Milk composition (fat and protein) was measured from samples collected during herd tests in mid October 2008, mid December 2008, mid February 2009 and early April 2009. Each herd test sampling period lasted for $48 \mathrm{~h}$ with samples being collected from every milking. A $24 \mathrm{~h}$ milk yield was calculated for individual cows using milking interval and milk yield data. Total fat and protein yield/cow/day or milksolids (MS) yield, was then estimated using the individual fat and protein percentages measured in the milk samples.

Table 1 Modelled Farm physical characteristics and MS yield for two farmlets (1 AMS) and two scaled up farm systems (4 AMS) based on actual field trial farmlet performance.

\begin{tabular}{lrrrr}
\hline Physical Characteristics & GRASS & GRASS+ & GRASS Large & GRASS+ Large \\
Peak cows & 92 & 72 & 368 & 288 \\
Effective ha & 28 & 20 & 115.2 & 80.0 \\
Cows/ha & 3.2 & 3.6 & 3.2 & 3.6 \\
Number of AMS & 1 & 1 & 4 & 4 \\
Total milksolids (fat+protein) (kg) & 33572 & 30073 & 134286 & 365 \\
Milksolids/cow (kg) & 365 & 418 & 1168 & 120293 \\
Milksolids/ha (kg) & 1168 & 1504 & 33572 & 1504 \\
Milksolids/AMS (kg) & 33572 & 30073 & 1.5 & 30037 \\
Milking frequency & 1.5 & 1.8 & 262 & 1.8 \\
Days in milk & 262 & 267 & 267 \\
\hline
\end{tabular}


Table 2 Model assumptions.

\begin{tabular}{|c|c|}
\hline Item & Assumption \\
\hline Milk payout (\$/kg MS) & $\$ 5.50$ \\
\hline Capital (milking facilities) & $\begin{array}{l}\text { Includes AMS, compressors, milk line, buffer vat and cooling, building based } \\
\text { on Greenfield Farm design }\left(\$ 1200 / \mathrm{m}^{2}\right) \text {, selection units, EID, silo }\end{array}$ \\
\hline Labour & $\begin{array}{l}\text { Includes paid and unpaid labour. Manager }(\$ 75000 / \mathrm{yr} \text { ) and assistant }(\$ 45000 \text { / } \\
\text { yr). Labour ratios (/cow) based on Hedley et al. (2006) and adjusted to ac- } \\
\text { count for a } 50 \% \text { reduction in milking duties, and no change for non-milking } \\
\text { duties (Jago et al. 2006). }\end{array}$ \\
\hline Service cost/AMS & $\$ 10000$ \\
\hline Animal health ${ }^{1}$ & $\$ 71 /$ cow \\
\hline Breeding $^{1}$ & $\$ 42 /$ cow \\
\hline Dairy $^{1}$ & $\begin{array}{l}\$ 21 / \text { cow for GRASS+ as close to twice daily milking then add } 5 \% \text { for ad- } \\
\text { ditional milkings in GRASS }\end{array}$ \\
\hline Electricity ${ }^{1}$ & $\$ 32 /$ cow adjusted up $4.3 \%$ for additional milkings in GRASS \\
\hline Silage conserved on milking platform & $\$ 0.20 / \mathrm{kgDM}$ \\
\hline Bought in silage & $\$ 0.25 / \mathrm{kgDM}$ \\
\hline Meal & $\$ 500 / t$ as fed \\
\hline Fertiliser (including $\mathrm{N})^{1}$ & $\$ 611 / \mathrm{ha}$ \\
\hline Stock grazing & $\begin{array}{l}\text { Young stock } \$ 7.8 / \text { head/wk } 52 \text { weeks, } 25 \% \text { of herd, assume calves on plat- } \\
\text { form, }+6 \text { weeks winter grazing for whole herd at } \$ 15 / \text { head/wk }\end{array}$ \\
\hline Regrassing ${ }^{1}$ & $\$ 65 /$ ha \\
\hline Weed and pest ${ }^{1}$ & $\$ 30 / \mathrm{ha}$ \\
\hline Vehicle and fuel ${ }^{1}$ & $\$ 180 /$ ha \\
\hline Repairs and maintenance ${ }^{1}$ & $\$ 308 / \mathrm{ha}$ \\
\hline Freight and general ${ }^{1}$ & $\$ 49 / \mathrm{ha}$ \\
\hline Standing charges and administration ${ }^{1}$ & $\$ 94 /$ cow \\
\hline Depreciation & $\begin{array}{l}25 \text { years ( } 4 \% \text { ) for buildings and yards, } 10 \text { years }(10 \%) \text { for milking equipment, } \\
\text { resale value of } \$ 70000 / \text { AMS }\end{array}$ \\
\hline Interest & $9 \%$ cost of capital \\
\hline Capital for ROA calculation & $\begin{array}{l}\text { Includes } \$ 38000 / \text { ha land value, dairy plant and buildings (capital listed } \\
\text { above), other machinery, livestock ( } \$ 1500 / \text { head), shares at } \$ 4.52 \text { ea. }\end{array}$ \\
\hline
\end{tabular}

${ }^{1}$ DairyNZ Economic Farm Survey 2008/2009

Figure 2 Rising plate meter height readings for pre- and post-grazing pasture covers for the GRASS and GRASS+ farmlets.

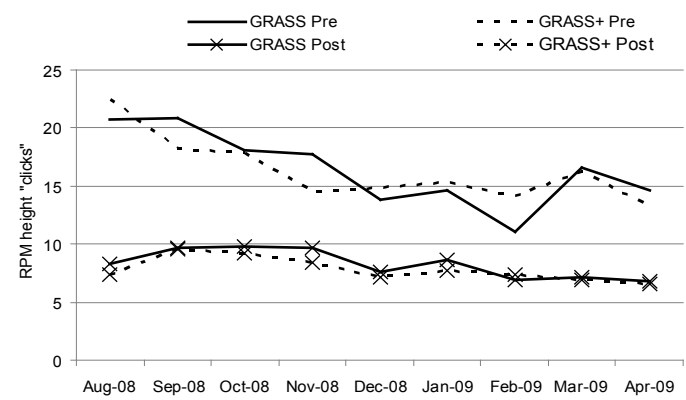

\section{Economic evaluation}

The physical results of the farm systems trial were used as model inputs to determine the economic performance of the two production systems (see Jago et al. 2006). Farm physical characteristics for the two
Table 3 Feed and performance measures for the GRASS and GRASS+ farmlets.

\begin{tabular}{|c|c|c|}
\hline & GRASS & GRASS+ \\
\hline Number of cows & 92 & 72 \\
\hline Meal (kg DM/cow) & 116 & 743 \\
\hline $\begin{array}{l}\text { Silage (not grown on milking platform, } \\
\mathrm{kg} \mathrm{DM} / \mathrm{cow} \text { ) }\end{array}$ & 0 & 284 \\
\hline Total non home-grown feed (kg DM/cow) $)^{1}$ & 116 & 1027 \\
\hline $\begin{array}{l}\text { Total non home-grown feed } \\
\text { (\% of diet })^{1}\end{array}$ & 2 & 18 \\
\hline Milksolids (fat + protein)/cow(kg) & 365 & 418 \\
\hline Milksolids/ha (kg) & 1166 & 1504 \\
\hline Milksolids/AMS (kg) & 33572 & 30073 \\
\hline Total milk yield/cow (kg/cow) & 4420 & 5092 \\
\hline Average milking frequency (milkings per day) & 1.5 & 1.8 \\
\hline $\begin{array}{l}\text { AMS utilisation at peak } \\
\text { (\% time occupied/day, Nov) }\end{array}$ & 81 & 74 \\
\hline Days in milk & 262 & 267 \\
\hline
\end{tabular}

${ }^{1}$ Feed not grown on the milking platform 
Table 4 Model outputs assuming a milk price of $\$ 5.50 / \mathrm{kg} \mathrm{MS}$.

\begin{tabular}{|c|c|c|c|c|}
\hline & GRASS & GRASS+ & GRASS Large & GRASS+ Large \\
\hline \multicolumn{5}{|l|}{ DAIRY CASH INCOME } \\
\hline Milk & 184643 & 165403 & 738574 & 661613 \\
\hline Other & 9844 & 7704 & 39376 & 30816 \\
\hline Total & 194487 & 173107 & 777950 & 692429 \\
\hline \multicolumn{5}{|l|}{ Cash farm working expenses (\$) } \\
\hline Labour & 29614 & 28421 & 101100 & 98400 \\
\hline Service costs & 10000 & 10000 & 40000 & 40000 \\
\hline Animal health & 6532 & 5112 & 15456 & 12096 \\
\hline Breeding & 3864 & 3024 & 12512 & 9792 \\
\hline Dairy costs & 1588 & 1512 & 6350 & 6048 \\
\hline Electricity & 2404 & 2304 & 9615 & 9216 \\
\hline Feed made (silage) & 7600 & 1600 & 15200 & 3200 \\
\hline Feed - bought in silage & 0 & 5112 & 0 & 20448 \\
\hline Feed - bought in grain & 5336 & 26748 & 21344 & 106992 \\
\hline Fertiliser (incl N) & 17597 & 12220 & 70387 & 48880 \\
\hline Stock grazing & 9329 & 13781 & 37315 & 55123 \\
\hline Regrassing & 1872 & 1300 & 7488 & 5200 \\
\hline Weed and pest & 864 & 600 & 3456 & 2400 \\
\hline Vehicles and fuel & 5184 & 3600 & 20736 & 14400 \\
\hline Repairs and maintenance & 8870 & 6160 & 35482 & 24640 \\
\hline Freight and general & 1411 & 980 & 5645 & 3920 \\
\hline Standing charges & 4784 & 3744 & 19136 & 14976 \\
\hline Administration & 3864 & 3024 & 15456 & 12096 \\
\hline FARM WORKING EXPENSES (\$) & 120713 & 129242 & 450294 & 498483 \\
\hline (/kg MS) & 3.60 & 4.30 & 3.35 & 4.14 \\
\hline Cash operating surplus & 73775 & 43865 & 327656 & 193946 \\
\hline Depreciation & 51242 & 51199 & 108065 & 107892 \\
\hline DAIRY OPERATING PROFIT (\$) & 22533 & -7334 & 219591 & 86054 \\
\hline Capital (\$) & 420418 & 419985 & 1261000 & 1259000 \\
\hline Interest & 37838 & 37799 & 113490 & 113310 \\
\hline Operating profit - interest & -15305 & -45132 & 106101 & -27256 \\
\hline Cost of production $(/ \mathrm{kg} \mathrm{MS})^{1}$ & 6.25 & 7.26 & 5.00 & 5.98 \\
\hline Asset value ${ }^{2}$ & 1833000 & 1452000 & 6840000 & 5317000 \\
\hline Return on asset (\%) & 1.2 & 0.5 & 3.2 & 1.6 \\
\hline
\end{tabular}

Table 5 Sensitivity analyses for economic performance of the four farming systems with a milk price payout ranging from $\$ 4.50$ to $\$ 6.50 / \mathrm{kg}$ milksolids, assuming input costs remain constant.

\begin{tabular}{|c|c|c|c|c|c|}
\hline & $\begin{array}{l}\text { Milk Price } \\
\text { (\$/kgMS) }\end{array}$ & GRASS & GRASS+ & GRASS Large & GRASS+ Large \\
\hline \multirow[t]{3}{*}{ Operating profit } & $\$ 4.50$ & -11039 & -37407 & 85304 & -34239 \\
\hline & $\$ 5.50$ & 22533 & -7334 & 219591 & 86054 \\
\hline & $\$ 6.50$ & 56104 & 22740 & 353877 & 206347 \\
\hline \multirow[t]{3}{*}{ Return on assets (\%) } & $\$ 4.50$ & -0.6 & -2.6 & 1.2 & -0.6 \\
\hline & $\$ 5.50$ & 1.2 & -0.5 & 3.2 & 1.6 \\
\hline & $\$ 6.50$ & 3.1 & 1.6 & 5.2 & 3.9 \\
\hline
\end{tabular}


farmlets, two larger farms (based on farmlet production and physical characteristics scaled four-fold: GRASS Large and GRASS + Large ) and the model assumptions are presented in Tables 1 and 2, respectively. The comparisons are based on the number of AMS installed as a constant ( 1 or 4 AMS), with land and cow numbers reflecting the different farming systems. The GRASS system is low input, with subsequently lower yields achieved per cow and longer durations between milkings. Based on each AMS performing 140 milkings per day, the GRASS system can therefore operate with more cows per AMS on a lower milking frequency. This requires additional land and cows compared with the GRASS+ system. The GRASS+ system is high input with higher yielding cows requiring more frequent milking. The higher milking frequency reduces the number of cows able to be milked per AMS to achieve the same number of daily milkings/AMS. Less land and cow numbers are therefore required for the GRASS+ system. Comparing economic performance of 4-AMS installations was selected based on obtaining a herd size similar to the national average of 360 cows (NZ Dairy Statistics 200809, http://www.dairynz.co.nz/page/pageid/2145848113/ New_Zealand_Dairy_Statistics_2008-09).

Capital cost for the dairy has been calculated using a base price of $\$ 253000$ for a single AMS (GRASS, GRASS+) and \$223000 per AMS for the GRASS Large, and GRASS+ Large farms. The model assumes there are two remote selection units ( $\$ 30000 /$ unit) for each of the GRASS and GRASS+ farms and four remote selection units for each of the GRASS Large and GRASS+ Large farms. Capital costs including land, livestock, plant and machinery have been included in the return on assets calculation (Table 2).

Feed volumes (silage conserved, concentrate fed etc) were based on the field trial data. With the exception of milk payout, labour, service costs, interest and depreciation all model input costs were based on the DairyNZ Economic Farm Survey 2008/09. For sensitivity analysis at differing payouts, input costs were assumed to have remained constant.

\section{Results}

\section{Pasture and imported feed}

The calculated values for annual pasture eaten were 13.2 and $13.5 \mathrm{tDM} / \mathrm{ha}$ for GRASS and GRASS+, respectively, assuming $80 \%$ utilisation of pasture (Macdonald et al. 2001). Making the assumption that pasture utilisation was similar for each farmlet is justified by similar postgrazing residual estimates throughout the season (Fig. 2). Post-grazing target residuals of 7 to 8 "clicks" were obtained on both farmlets for the majority of the season. However, during the spring when pre-grazing covers were higher, it was more difficult to reach target residual heights. Total harvested pasture silage was estimated at $38 \mathrm{t} \mathrm{DM}$ on the GRASS farmlet and $8 \mathrm{t}$ DM harvested from the GRASS + farmlet, using pre- and post- cutting pasture measurements.

\section{Production performance}

The GRASS+ herd produced $53 \mathrm{~kg} \mathrm{MS} / \mathrm{cow}$ and 338 $\mathrm{kg} \mathrm{MS} / \mathrm{ha}$ more than from the higher feed input and stocking rate GRASS herd (Table 3). Despite lower per cow production, the low input GRASS herd produced more milk and MS per AMS as a result of the higher ratio of cows per AMS. The average milking frequency was higher for the GRASS+ herd, being close to twice daily milking, but the GRASS herd achieved a higher AMS utilisation.

\section{Economic evaluation}

Using the assumptions presented in Table 2, the model output (Table 4) shows that at a milk price of $\$ 5.50$ / $\mathrm{kg}$ MS, the lower input GRASS system has a higher operating profit and return on assets than the GRASS+ system because of higher milk income and lower feed costs (including winter grazing and fertiliser). These cost savings outweigh higher labour, animal health, breeding and other farm costs which result from the larger land area and more cows on the GRASS farmlet.

The increased scale resulted in an improved financial performance for both farm systems. A sensitivity analysis for milk price showed that at the lower milk price of $\$ 4.50 / \mathrm{kg}$ MS, all but the larger GRASS system have a negative operating profit (OP) (Table 5). At $\$ 6.50$ all the systems have a positive operating profit, with the larger GRASS system providing 5.2\% return on assets.

\section{Discussion}

This field study has shown that AMS can be successfully integrated into both all-pasture and high supplementary feed spring-calving dairy systems. The production performance of the two systems was consistent with farms managed to best-practice standards and conventional batch milking methods as described by Hedley et al. (2006). The GRASS+ farmlet produced more MS/ha, harvested similar pasture, and had less surplus pasture for conservation, while the GRASS system produced less MS/cow, had a shorter lactation and was able to produce sufficient surplus pasture to maintain the herd with feed from the milking platform.

Growing and utilising a large amount of pasture is necessary to maximise the profitability of pastoral dairy systems (Macdonald et al. 2008). Both farmlets grew over $15 \mathrm{t} \mathrm{DM} / \mathrm{ha}$ which is comparable to wellmanaged farms in the region (Hedley et al. 2006) and similar to the net pasture accumulation of $16.2 \mathrm{t} \mathrm{DM} /$ 
ha/yr reported for the Greenfield research farm in the 2004/2005 season (Davis et al. 2006). Key to achieving high pasture utilisation is the ability to achieve target grazing residuals. In a system where cows are able to leave the grazing area voluntarily this could present a problem, particularly when the incentive to leave is access to a fresh area of pasture. However, the data shown here, along with those described by Davis et al. (2006), indicates that voluntary milking through automatic milking systems need not be a barrier to harvesting large amounts of grazed grass.

Although cows in the GRASS + system achieved a higher milking frequency and production per cow, less total MS were harvested per AMS. In grass-based systems where one of the major drivers of profitability is cost of production, it will be important to fully utilise each AMS and consideration should be given to how this can best be achieved. In this study, the economic evaluation showed that the scaled up all-pasture system with a high ratio of cows per AMS was more profitable than the more intensive system over a range of milk prices. This model did not account for increasing costs of inputs with higher payouts. However, it can be surmised that the input costs for the GRASS+ farm would have disproportionately increased compared to the GRASS system. For instance, at a payout of $\$ 6.50$ operating profit increases from 1.7, with current assumption of no change in input costs, to 1.8 times greater for GRASS compared to GRASS+ (OP of \$331 362 and $\$ 184423$, respectively) when a 5\% increase in farm working expenses are included in the model for the 4-AMS farms.

\section{Conclusions and Implications}

Profitable pastoral dairy systems are based on a compromise between production per cow and per hectare. The cost of production imposes a limitation on yield per cow through imported feed costs. An additional consideration for an automatic milking farm is production per AMS. The field study has shown that AMS can be successfully integrated into both all-pasture and pastoral dairy production systems incorporating moderate levels of supplementary feed (within Production System 3). Increasing the number of cows milked and reducing the individual cow milking frequency can increase milk production per AMS. The implications of this study are that the fundamental requirements of profitable pastoral dairy systems, to produce high quantities of pasture and achieve high pasture consumption, are not compromised with the introduction of automatic milking systems, although with current costs profitability is marginal at a milk price below $\$ 5.50 / \mathrm{kg}$ MS.

\section{ACKNOWLEDGEMENTS}

The authors acknowledge the contribution of Rodger Jensen during the establishment phase of this project and Kevin Bright for technical support as well as DairyNZ farm staff for management of the Greenfield herd. This research was funded by DairyNZ Inc.

\section{REFERENCES}

DairyNZ Economic Survey 2008-09. http://www. dairynz.co.nz/page/pageid/2145845982/ DairyNZ. Economic Survey 2008-09.

Davis, K.; Jago, J.; Wielczko, R.; Copeman, P.; Bright, K.; Woolford, M. 2005. Optimising milking efficiency to maximise milk output from an automated milking system. Proceedings of the New Zealand Society of Animal Production 65: 271-275.

Davis, K.L.; Jago, J.G.; MacDonald, K.A.; McGowan, J.E.; Woolford, M.W. 2006. Pasture utilisation in a pastoral automated milking system. Proceedings of the New Zealand Grassland Association 68: 81-86.

Halachmi, I. 1999. Design methodology for robotic milking barn. PhD thesis. Wageningen.

Hedley, P.; Kolver, E.S.; Glassey, C.B.; Thorrold, B.S.; van Bysterveldt, A.; Roche, J.R.; Macdonald, K.A. 2006. Achieving high performance from a range of farm systems. Proceedings of the Dairy3 Conference 4: 147-165.

Jago, J.; Bright, K.; Copeman, P.; Davis, K.; Jackson, A.; Ohnstad, I.; Wieliczko, R.; Woolford, M. 2004. Remote automatic selection of cows for milking in a pasture-based milking system. Proceedings of the New Zealand Society of Animal Production 64: 241245.

Jago, J.; Davis, K.; Newman, M.; Woolford, M. 2006. An economic evaluation of automatic milking for New Zealand dairy farms. Proceedings of the New Zealand Society of Animal Production 66: 263-269.

Jago, J., Davis, K.; Copeman, P.; Ohnstad, I.; Woolford, M. 2007. In-bail feeding and minimum milking interval effects on cow traffic and milking performance in a pasture based automatic milking system. Journal of Dairy Research 74: 1-8.

Macdonald, K. A.; Penno, J.W. 1998. Management decision rules to optimise milksolids production on dairy farms. New Zealand Society of Animal Production 58: 132-135.

Macdonald, K.A.; Penno, J.W.; Nicholas, P.K.; Lile, J.A.; Coulter, M.; Lancaster, J.A.S. 2001. Farm systems - Impact of stocking rate on dairy farm efficiency. Proceedings of the New Zealand Grassland Association 63: 223-227.

Nicol, A.M.; Brookes, I.M. 2007. The metabolisable energy requirements of grazing livestock. New Zealand Society of Animal Production 14: 151-172. 
NZ Dairy Statistics 2008-09. http://www.dairynz.co.nz/ page/pageid/2145848113/New Zealand Dairy Statistics 2008-089 (accessed 20 August 2010) Livestock Improvement Corporation, Hamilton, New Zealand.

Thomson, N.A.; Upsdell, M.P.; Hooper, R.; Henderson, H.V.; Blackwell, M.B.; McCallum, D.A.; Hainsworth, R.J.; MacDonald, K.A.; Wildermoth, D.D.; BishopHurley, G.J.; Penno, J.W. 2001. Development and evaluation of a standardised means for estimating herbage mass of dairy pastures using the rising plate meter. Proceedings of the New Zealand Grassland Association 63: 149-157. 
